\title{
The Reception and Consumption of Eastern Goods in Roman Society
}

The Roman Empire received goods from eastern lands through a variety of overland routes crossing the Arabian Peninsula and Mesopotamia, and through seaborne trade via the Red Sea and the Indian Ocean. ${ }^{1}$ In particular, the sea-routes which utilised the monsoon winds of the Indian Ocean enabled a significant volume of goods to be imported from the East on ships which may often have been of several hundred tons of capacity. ${ }^{2}$ The scale of the trade was significant enough for Pliny to claim that 100 million sesterces were being annually sent to India, China and Arabia. ${ }^{3}$ The veracity of these figures has come in for some debate, especially with the publication of a document known as the Muziris Papyrus which reveals that a shipment of nard, ivory and textiles received at one of the Egyptian Red Sea ports in the second century $\mathrm{AD}$ was valued at the equivalent of roughly 7 million sesterces. ${ }^{4}$ It is nevertheless clear, particularly from the archaeological and numismatic evidence, that Roman trade with the East peaked in the first and second centuries AD followed by subsequent decline and a limited revival in the Late Roman period. ${ }^{5}$

\footnotetext{
${ }^{1}$ G. K. Young Rome's Eastern Trade: International Commerce and Imperial Policy, 31 BC - AD 305 (London, 2001); Peripl. M. Rubr. 39, 49, 56; Pliny NH 6.26.99-105.

${ }^{2}$ S. E. Sidebotham Berenike and the Maritime Spice Route (London, 2011) 195-96; see also E. J. Strauss Roman Cargoes: Underwater Evidence from the Eastern Mediterranean (UCL PhD Thesis, 2007) 100-02, 106-08; M. A. Cobb Roman Trade in the Indian Ocean during the Principate (Swansea PhD Thesis, 2011) 60-78, 147-51.

${ }^{3}$ Plin. NH 12.41.84.

${ }^{4}$ L. Casson 'P.Vindob G 40822 and the Shipping of Goods from India', BASP 23 (1986); also D. Rathbone, 'The 'Muziris' Papyrus (SB XVIII 13167): Financing Roman Trade with India' in S. Abd-El-Ghani and W. Farag (eds.), Alexandrian Studies in Honour of Mostafa el Abbadi (Alexandria, 2000); for an overview of the debates concerning the veracity of Pliny's figures see Cobb (n.2) 259-71.

${ }^{5}$ D. Peacock and L. Blue (eds.) Myos Hormos - Quseir al-Qadim: Roman and Islamic Ports on the Red Sea (Oxford, 2006); S. E. Sidebotham and W. Z. Wendrich (eds.) Report of the 1997 Excavations at Berenike and
} 
Traditionally scholars have regarded goods that were brought to the Roman Empire from lands such as India, China, East Africa and the southern Arabian Peninsula as luxuries, which were consumed by the wealthy and those of high social status. ${ }^{6}$ This is understandable given the significant costs that are mentioned in the literature for items such as pearls, gems and silks. Pliny mentions a rock-crystal ladle worth 150,000 sesterces and an opal ring that cost 2,000,000 sesterces. ${ }^{7}$ Such expenditure might represent more than the annual profits made on the landed property of many of the senatorial elite. ${ }^{8}$ However, more recently, Sidebotham set a trend by arguing that some of these eastern imports, especially spices and aromatics, held medicinal, funerary, religious and culinary importance in Roman society, and were therefore considered by the elite as necessities and not luxuries. Nevertheless, he still regards goods like precious gems, ivory and pearls as luxuries. ${ }^{9}$ This notion has gained a fair degree of acceptance and has appeared in some recent scholarship on trade with the East. ${ }^{10}$

the Survey of the Egyptian Eastern Desert, Including Shenshef (Lieden, 1999); Sidebotham (n.2) 63, 244; Cobb (n.2) 93-94, 98-99, 239-50.

${ }^{6}$ See for example E. H. Warmington The Commerce Between the Roman Empire and India (London, 1928) 4042, 79-83; L. Casson [Introduction, Translation, and Commentary of] Periplus Maris Erythraei (Princeton, 1989) 15, 19; A. Dalby Dangerous Tastes: The Story of Spices (London, 2000a) 156; F. Wild, 'Sails, Sacking and Packing: Textiles from the First Century Rubbish Dump at Berenike, Egypt' in C. Alfaro, J. P. Wild, and B. Costa (eds.), Purpureae Vestes: Textiles y tintes del Mediterráneo en época romana (Valencia, 2004) 61-67; J. Keay The Spice Route (London, 2005) x-xi; R. L. Smith Trade in World History (London, 2009) 77, 90.

${ }^{7}$ Pliny $H N 37.10 .29$ (rock-crystal), 37.21.81-82 (opal ring).

${ }^{8}$ W. M. Jongman, 'The early Roman empire: Consumption' in W. Scheidel, I, Morris, and R. Saller (eds.), The Cambridge Economic History of the Greco-Roman World (Cambridge, 2007) 600-01.

${ }^{9}$ S. E. Sidebotham Roman Economic Policy in the Erythra Thalassa 30 B.C. - A.D. 217 (Leiden, 1986) 45, 176.

${ }^{10}$ See for example D. P. S. Peacock and D. Williams (eds.), Food for the Gods New Light on the Ancient Incense Trade (Oxford, 2007); R. Tomber Indo-Roman Trade: From Pots to Pepper (London, 2008). 
This article argues that the notion of these goods being either luxuries or necessities is problematic and misleading, and imbues them with particular static qualities. It is not possible to categorise any of these goods as luxury items or necessities, since such terms can only be applied when they are being used in a certain context, they are not qualities which are inherent in the goods themselves nor can they be seen as permanent or mutually exclusive. As shown below, many eastern goods could form part of a religious or funerary ceremony, in which they simultaneously fulfil a (necessary) moral obligation, and act as a means of (luxurious) social display and even excess. The distinction between luxury and necessity also masks the subjective interpretations of Roman contemporaries, and the multiple meanings and variety of perspectives in which these goods were held.

The argument that the concepts of luxury and necessity are not mutually exclusive is not as counterintuitive as might first appear. Anthropological and sociological scholarship of the last several decades has argued that goods can convey social and rhetorical meanings within a culture. ${ }^{11}$ These goods do not hold inherent values but are judged in their relation to other goods and how they are used 'in motion', that is to say in what contexts. ${ }^{12}$ In particular Appadurai notes that "demand" is the result of social practices and classifications "rather than a mysterious emanation of human needs', that consumption is a social and relational process, and most importantly that a contrast between luxury goods and necessities is problematic,

\footnotetext{
${ }^{11}$ M. Douglas and B. Isherwood The World of Goods: Towards an Anthropology of Consumption (London, 1978) 72-73; A. Appadurai, 'Introduction: Commodities and the Politics of Value' in A. Appadurai (ed.) The Social Life of Things: Commodities in Cultural Perspective (Cambridge, 1986) 3.

${ }^{12}$ Douglas and Isherwood (n.11) 72-73; Appadurai (n.11) 3-5, 16; see also I. Kopytoff, 'The Cultural Biography of things: Commoditization as Process' in A. Appadurai (ed.) The Social Life of Things: Commodities in Cultural Perspective (Cambridge, 1986), 76-80.
} 
especially because the former respond to political necessity as "incarnated signs". The labels applied to these goods are not fixed but shift over time. ${ }^{13}$

Another inherent problem in the use of the term "luxury" is that it is often traditionally felt to imbue some form of 'moral slur' and it is only with the industrial period and the collapse of sumptuary laws that "luxuries" have been left to the "free play of the marketplace and of fashion. ${ }^{14}$ In contrast earlier social discourse of the pre-Industrial world tended to view "luxury" goods in a moral and societal sense, as often seen in the imposition of sumptuary laws. ${ }^{15}$ Much of the philosophical discourse in the Roman period condemned luxury in ethical terms, arguing that it was emasculating and engendered weakness, both moral and physical. ${ }^{16}$ However, as Valerius Maximus notes, luxury is easier to denounce than to avoid. ${ }^{17}$ One of the fundamental problems in interpreting the ancient literature is that the authors assumed their audience knew what luxury meant and therefore offered little in the way of definition but rather conventional polemic. ${ }^{18}$ Furthermore even the understanding of what was luxurious, tasteful, or vulgar was, and still is, a subjective matter. Nevertheless, it will be shown that in the eyes of many of the Roman elite the concept of luxury and necessity could be held simultaneously.

The best manner in which to convey this argument is to examine the various social functions and contexts in which eastern goods feature, namely the religious, funerary,

\footnotetext{
${ }^{13}$ Appadurai (n.11), 29, 31-32, esp. 38-40.

${ }^{14}$ Douglas and Isherwood (n.11) 179; Appadurai (n.11) 38-39.

15 J. Sekora Luxury The Concept in Western Though, Eden to Smollet (Baltimore, 1977) 1, 4, 112-13; see also A.

Wallace-Hadrill Rome's Cultural Revolution (Cambridge, 2008), 319-29.

${ }^{16}$ Val. Max. 2.2.6 (corruption of manners); Sen. Ep. 19.10; 82.2 (emasculation); 55.1; 92.10; 95.15, $19 ; 123.7$

(weakening).

17 Val. Max. 9.1.

${ }^{18}$ Sekora (n.15), 48.
} 
medicinal, and culinary (the latter will be examined in the broader context of public eating or banquets). By discussing these goods in the categories cited by Sidebotham as involving the necessary use of certain eastern goods, it will be possible to show how this labelling can distort the more complex social realities.

\section{The Luxury of Necessity}

\section{Banquets}

The term banquet is used here as an overarching category for communal dining which involved guests and thus elements of display and judgment by those present. Many of the important elements of a banquet involved products derived from trade with the East. The most obvious component comprised the spices used to flavour food and drink, like spiced wines, peppered rissoles, and cinnamon flavoured olive oil. ${ }^{19}$ A variety of spices appears in recipes recorded by Apicius, including malabathrum in oyster sauce, malabathrum and spikenard in a silphium sauce, and ginger in stews ${ }^{20}$ However, it was not simply the spices in the dishes that were important features of the banquet. The furniture on which guests reclined and on which food was served could include items decorated with tortoiseshell veneer, ivory legs and onyx feet. ${ }^{21}$ The drinking cups might be of fine crystal or precious metals encrusted

\footnotetext{
${ }^{19}$ Apicius 1.1.1-2 (spiced wines), 2.1.1-7, 2.2.1-9 (rissoles, including peacock rissole), 2.3.1; Verg. G. 2.466 (cinnamon olive oil).

${ }^{20}$ Apicius 1.13.1-2 (oyster sauce), 1.16.1-2 (silphium sauce), 4.5.1 (turnover stew); for Apicius the gourmet see Mart. Epig. 3.22.

${ }^{21}$ Mart. Epig. 14.87; Pliny HN 16.8.43 (tortoiseshell veneer), 36.12 .7 (onyx feet of chair); Juvenile Satires 11.120-121 (citrus and ivory table); Livy 41.20 .1 (ivory chair); Sen. Ep. 110.12 (jewelled furniture).
} 
with gems from India. ${ }^{22}$ Dress and personal adornment were also important elements at a banquet as indicated by Petronius' sardonic statement that ladies might be decked out in pearls in order to spread their legs on a stranger's couch. ${ }^{23}$ Connected to this was the use of perfumes by those attending a convivium (evening party), which might use plant products from the East, such as cinnamon, cassia and nard ${ }^{24}$ and these were not just worn by women but also by men. ${ }^{25}$

One might ask to what extent such elements at a banquet were necessary, or to put it another way, expected by guests. Pliny was surprised at, and dismissive of, the popularity of pepper, arguing that its only attraction is its bitter flavour, and 'to think we travel to India for it. ${ }^{26}$ This popularity is seen in the cook book of Apicius where pepper is included in almost all his recipes, but the extent to which it was added to food for its flavour as opposed to its exotic appeal is difficult to discern. Persius satirises the miserly man who reserves pepper for his birthday and then only sprinkles on a little. ${ }^{27}$ The passage suggests that this (fictional) individual, although his social status is not made clear, considered pepper a rare treat rather than an obligatory element in his meals. The inference being that for someone of high social status and sophistication large quantities of pepper may have been seen as important. This has

\footnotetext{
${ }^{22}$ Pliny $H N$ 37.6.2, 9-10.2; a rock-crystal drinking cup (skyphos) has been found at Pompeii - now in the Museo Nazionale Archeologico Naples.

${ }^{23}$ Petron. 55.6.9-16.

${ }^{24}$ See Lucr. 4.11.31-33; Val. Max. 2.6.1; Sen. Vita Beata. 11.4; Pliny HN 13.1-2.1-2; Juv. 6.297, 303, 9.128-9, 11.121; Suet. Calig. 37, Ner. 27, 30; though it is important not to forget the food-Mart. Epig. 3.12.

${ }^{25}$ J. Griffin 'Augustan Poetry and the Life of Luxury', JRS 66 (1976), 93.

${ }^{26}$ Pliny HN 12.14.29 - Translation from J. F. Healy (London, 1991).

${ }^{27}$ Pers. 6.18-21.
} 
parallels with the medieval period where in many European societies the use of astonishing quantities of spices in food reflected style and splendour. ${ }^{28}$

The widespread consumption of such spices like pepper raises the question of whether its popularity undermines the notion that it was a luxury, and strengthens the notions that it was a necessity. Attacks on luxury often focused on lavish food, because of its ephemeral nature, the combination of different foodstuffs and spices within single dishes, and because it used up a large part of an individual's income. ${ }^{29}$ As we have seen from Pliny's comment, pepper does not escape this censure. Thus it can be seen that pepper was a necessary (or at least important) element of luxury cuisine, in the context of an extravagant banquet. Whether pepper was eaten everyday as part of more ordinary cuisine is difficult to say, but as Plutarch noted fine cuisine and furnishings were reserved for banquets, whereas when one ate alone or with close intimates the food tended to be much plainer, with simpler furnishings. ${ }^{30}$

The use of extravagance to entice guests was a strategy commented upon by contemporaries. Indeed Martial mocks Pomponius by stating that his apparent popularity comes not from his eloquence but from his cuisine, ${ }^{31}$ and sometimes the failure to provide lavish banquets was condemned. ${ }^{32}$ In these contexts spices were necessary precisely because extravagance use of them was a means to attract guests, and to advertise and hopefully raise one's social status. They were part of the excess at banquets which could culminate in some

\footnotetext{
${ }^{28}$ P. Freedman Out of the East: Spices and the Medieval Imagination (London, 2008), 6.

${ }^{29}$ C. Edwards The Politics of Immorality in Ancient Rome (Cambridge, 1993), 186 (ephemeral nature); P.
} Garnsey Food and Society in Classical Antiquity (Cambridge, 1999), 113 (percentage of income).

${ }^{30}$ Plut. Mor. 528a; For the peculiarity of extravagant dinning without company see J. H. D'Arms 'Performing Culture: Roman Spectacle and the Banquets of the Powerful', in B. Bergmann and C. Kondonleon (eds.), The Art of Ancient Spectacle (London, 1999) 312-13.

${ }^{31}$ Mart. Epig. 6.48; see also Sen. Ep. 19.11 (attempts to win friends through lavish banquets).

${ }^{32}$ Mart. Epig. 2.44. 
indulgent individuals vomiting up what they had consumed. ${ }^{33}$ As for some of the more expensive items at the banquet, including veneered furniture and jewelled cups it seems that even among the elite only the wealthiest could afford such items. Martial comments how Eros would weep in the market for he could not afford the items displayed, and while people mocked him for it, they too wept inside. ${ }^{34}$ Indeed banquets could cost millions of sesterces. ${ }^{35}$ Display or consumption of the items discussed would certainly mark the host out as a prosperous and wealthy individual and could generate prestige as a result. It seems that for those of the elite who could afford such items, the very costly furniture, serving dishes and cups were as necessary a part of the luxurious extravagance on display as the spices used in the dishes served.

\section{Medicines}

The term "necessity" might seem particularly appropriate in the context of medicine, since few people would consider their health to be a frivolous issue. Nevertheless, as shown below, the use of eastern goods in medicine did not escape the charge of being superfluous. It is in medicinal contexts that eastern spices and aromatics are mentioned most frequently, a reflection of the fact that there is a much larger surviving corpus of works that record pharmacological information, as seen with Dioscorides, Celsus, Pliny, and Galen. It is notable that the predominance of pepper in the recipes of Apicius contrasts with a much broader range of spices that are mentioned as ingredients in medications. Cuisine and medicine, however, were often considered to be interrelated in the ancient world, as they

\footnotetext{
${ }^{33}$ Plut. Mor. 524 a.

${ }^{34}$ Mart. Epig. 10.80; see also 9.59 on Mamurra inspecting carefully many fine objects, like sardonyx, green gems, and tortoiseshell couches only to buy to a few cheap cups; Sen. Ep. 76.14 - also mentions the costliness of couches and cups.

${ }^{35}$ Sen. Ep. 95.41.
} 
were in the medieval. ${ }^{36}$ Furthermore many of these plant products also appeared in cosmetics and perfume. ${ }^{37}$ Theophrastus stated that it should be expected that perfumes would have medicinal properties in view of the virtue of the spices from which they are composed. ${ }^{38}$ The greater variety of spices and aromatics used in medicines may relate to the fact that some of these products had a bitterness or pungency that was felt to be effective in medicine, but perhaps unappealing to taste. This, however, was not always a bar to consumption, for Pliny notes that some people went as far as to put bitter unguents their drinks in order that through such lavishness both taste and smell were indulged at the same time. ${ }^{39}$

It is worth noting that the effectiveness of these medicines is not the issue here, but rather the belief that they were. Pliny argued that nature provided medicine for the Romans in the form of traditional recipes of herbs and vegetables still used by the poor. In contrast the rich were spending substantial sums on remedies from India and Arabia because of deceitful and ingenious men who concocted complicated mixtures that defied explanation, but appeared to be effective. ${ }^{40}$ Despite this tone of disapproval, Pliny, without apparent scepticism, proceeds to describe general opinions of their efficacy. For example, he states that one medicine is called enhaemon, 'because of its remarkable effect in closing the scars of

\footnotetext{
${ }^{36}$ For the interconnection of diet and health in the ancient world see J. M. Wilkins and S. Hill Food in the Ancient World (Oxford, 2006), 213-44; for the medieval world see Freedman (n.28), 4-5, 60; generally Dalby (n.6), 16.

${ }^{37}$ K. Olson Dress and the Roman Woman Self-Presentation and Society (London, 2008), 67.

${ }^{38}$ Theophr. de Odoribus 59.

${ }^{39}$ Pliny $H N$ 13.4-5.3; however Theophrastus notes that sometimes perfumes could be added to wine because they had a sweet flavour (de Odoribus 51) - G. Reger 'The Manufacture and Distribution of Perfume', in Z. H. Archibald, J. K. Davies, and V. Gabrielsen (eds.), Making, Moving, and Managing: The New World of Ancient Economies 323-31 BC (Oxford, 2005), 260.

${ }^{40}$ Pliny HN 24.1.4-5.
} 
wounds. ${ }^{41}$ Other sources such as Celsus and Dioscorides also speak of the effectiveness of these plant products. It seems that while objections were raised to the extravagant expense of these medicines, their potency was widely believed in.

There was an enormous range of medicines for the treatment of various ailments. The literary sources mention a variety of treatments that employed eastern goods. Celsus states that frankincense, myrrh, Arabic gum, and cardamom were used to agglutinate (cause to adhere) wounds. ${ }^{42}$ Dioscorides mentions the use of cassia for skin lesions and cardamom for back and belly pain. ${ }^{43}$ However, while some plant products or compounds were for serious ailments, others could be perceived as more trivial; for example malabathrum was sometimes used to freshen the breath, perhaps to cover up the previous night's drinking. ${ }^{44}$ Other uses might seem elective (depending upon the circumstance), such as using cardamom as a fumigant to abort a foetus. ${ }^{45}$ Some of the ancient sources claim this was done simply to ensure a firm and beautiful body; notably Ovid proclaims a woman will harm her womb in order to appear beautiful. ${ }^{46}$

The degree to which one chooses to deem these medical issues, and the medicines used to treat them, as serious, trivial or elective, is subjective and personal and what was considered necessary or optional was probably influenced by the circumstances of those that could afford them. It is likely that contemporary fashions in medical thought and the ability

\footnotetext{
${ }^{41}$ Pliny HN 12.38.77-78 - translation from H. Rackham Loeb (London, 1945).

${ }^{42}$ Celsus, Med. 5.2.1.

${ }^{43}$ Dioscorides De Materia Medica 1.5 (cardamom), 1.12 (cassia).

${ }^{44}$ Mart. Epig. 1.87 (drinkers breath); Pliny HN 23.48.4 (malabathrum mouth freshener).

${ }^{45}$ Dioscorides De Materia Medica 1.5 .

${ }^{46}$ Olson (n.37), 69; Ov. Nux 23; see also Prop. 2.15.21-2; Ov. Ars Am. 3.81-2; 785-6; Sen. Helv. 16.3; Sor. Gyn. 160, Gell NA 12.1.8 (mother's refusal to breastfeed).
} 
of medical men to play on the wealthy individuals' sense of mortality influenced choices. ${ }^{47}$ Consequently the use spices, aromatics and other eastern goods in medicines would not have been seen as necessary in all contexts, and would have been a matter of debate and conflicting opinion.

\section{Religious Rituals}

The use of rituals and offerings to appease the gods was common religious practice, although some individuals such as Lucretius occasionally censured these activities for being pointless. ${ }^{48}$ Eastern goods sometimes formed part of these ritual offerings. Pliny gives the impression that many of these goods were a recent edition to ritual practice, stating that Pompey Magnus was the first person in Rome to dedicate a bowl of myrrh to the gods, doing so at the temple of Jupiter. ${ }^{49} \mathrm{He}$ also states that Vespasian was the first person to offer up processed cinnamon in embossed gold, doing so in the temple of Concordia, although even before this Livia dedicated a large root of cinnamon to her late husband Augustus. ${ }^{50}$ On the face of it, Pliny's statements indicate that such goods were part of innovations in religious rituals. Both Ovid and Pliny state that in earlier times before scents like myrrh and nard were offered up, what was formerly used to conciliate the gods was spelt and salt; the latter being more favourable to the gods in Pliny's opinion. ${ }^{51}$ However, historical evidence suggests that

\footnotetext{
${ }^{47}$ Pliny HN 24.1.4-5; Wilkins and Hill (n.36), 224; note the modern use of homeopathy and chiropractors.

${ }^{48}$ Lucr. 5.1197-1203; while not going as far as Lucretius, Seneca (Ep. 95.41) questioned aspects of ritual, including the throngs of devotes attracted by temple ceremonies.

${ }^{49}$ Pliny HN 37.7.18.

${ }^{50}$ Pliny $H N$ 12.42.19; however, Ovid claims that Augustus was the first to offer up cinnamon to Jupiter (Fast. 3.731-32).

51 Pliny $H N$ 12.41.18; Ov. Fast. 1.337-42; though at Fast 4.145-46, Ovid says that Fortuna Virilis assures prayers after a little incense, and also at Fast. 5.303, he states that he has often seen Jupiter restrain from
} 
frankincense and myrrh were being used by the population of Rome as early as the third century BC if not earlier. ${ }^{52}$

These comments can be connected to a wider moralising discourse that praised simpler and more traditional customs. ${ }^{53}$ Nevertheless it is also possible to discern from Pliny's comments that the actions of Pompey, Livia, and Vespasian were a means of advertising status and wealth through the value and novelty of their offerings, advertisements to their contemporaries of their munificence and status. ${ }^{54}$ This is also seen in accounts of other rulers such as Caligula, who in establishing a shrine to himself had many of the elite competing to be part of his priesthood, with exotic offerings like peacocks. ${ }^{55}$ It seems that a process developed whereby there was a constant need to find something more original or lavish by which the elite could make their mark. Plutarch characterises this process when he throwing thunderbolts when incense is offered; contrast Val. Max. 1.1.15, who mentions women offering incense to Ceres during the second Punic war.

${ }^{52}$ Keay (n.6), 32; C. Singer 'The Incense Kingdom of Yemen: An Outline History of the South Arabian Incense Trade', in D. P. S. Peacock and D. Williams (eds.), Food for the Gods New Light on the Ancient Incense Trade (Oxford, 2007), 6-7; N. Groom Frankincense and Myrrh: A Study of the Arabian Incense Trade (London, 1981), 5-6 - For mid-Republican uses of incense see Plautus, and also Cat. Agr. 134, where he states advise to address Janus, Jove and Juno with incense and wine.

${ }^{53}$ See J. Isager Pliny on Art and Society: The Elder Pliny's Chapters on the History of Art (London, 1991); T. Murphy Pliny the Elder's Natural History: The Empire in the Encyclopedia (Oxford, 2004); G. Parker 'Ex Oriente Luxuria: Indian Commodities and Roman Experience', Journal of Economic and Social History of the Orient 45.1 (2002); E. S. Ramage ) Urbanitas: Ancient Sophistication and Refinement (Oklahoma, 1973); A. Wallace-Hadrill 'Pliny the Elder and Man's Unnatural History’, Greece and Rome 37.1 (1990).

${ }^{54}$ For the value of novelty and price to display status see Wallace-Hadrill (n.5), 347-48, and D. Petrain 'Gems, Metapoetics, and Value: Greek and Roman Responses to a Third-Century Discourse on Precious Stones', TAPA 135 (2005), 348.

${ }^{55}$ Suet. Calig. 22.2-3; see also Vit. 13, where a gigantic dish was offered up to Minerva, including peacock brains among other expensive items. 
states that what was necessary and useful in religious rituals had been smothered by what is useless and superfluous. ${ }^{56}$ Yet for some, offering high-value eastern goods, like precious gems, was a perfectly acceptable way to honour the gods. ${ }^{57}$

Attempts to use extravagant religious offerings as a form of social display need not be viewed cynically, and there was nothing contradictory in Roman society between honouring the gods and simultaneously enhancing one's own prestige. In these contexts it was precisely the "luxurious" and exotic associations of these eastern goods which were sought. Not all offerings were undertaken with the aim of gaining social prestige. For example Martial states that he offered up heaps of incense to expiate the misfortune that was affecting his farm and killing his animals, although without success. ${ }^{58}$ The point is that these goods had many different uses and were perceived in many different ways. For some, incense was an unnecessary intrusion into religious ritual, for others it may have been necessary if not always effective, and again, others may have selected certain goods not only to honour the gods but also as a means of novel social display designed to impress their contemporaries. Thus any attempt to apply a universal label to these goods conceals the range of views and uses to which they were put in Roman society.

\section{Funerary Rites}

Honouring the dead was another aspect of Roman society that came with strong moral obligations. Funerals were very much public acts, all the more so for members of the elite where there were associated expectations of social and political display. ${ }^{59}$ Eastern goods were

\footnotetext{
${ }^{56}$ Plut. Mor. 527 d.

${ }^{57}$ See Philostr. VA. 1.10.1 and 2.40.3.

${ }^{58}$ Mart. Epig. 7.54.

${ }^{59}$ C. Edwards Death in Ancient Rome (London, 2007), 144; D. G. Kyle Spectacles of Death in Ancient Rome (London, 1998), 128.
} 
employed in rituals, most notably the use of incense, which had the practical function of covering up the smell of the decomposing body which could be on displayed for several days, keeping away insects and flies, as well as covering up the smell of burning flesh on the pyre. ${ }^{60}$ Pliny complained that incense was burned in heaps all across the Empire for funerals, but that only a few grains were being given to the gods. ${ }^{61}$ The extent to which this represented widespread use of incense or intensive use by the elite is unclear.

In any case, it was not just for practical reasons that such goods formed part of funerary rituals. These rituals were sometimes used as a means of promoting the honour and prestige of the family line. Appian even compared funeral processions to triumphs. ${ }^{62}$ It was precisely through conspicuous consumption that elite self-promotion could be achieved, and in this context eastern goods had a valuable role to play. At the funeral of Sulla, masses of spices and aromatics were contributed by the wealthy women of Italy, so much that they filled 210 litters, and with the surplus a huge figure of Sulla was made from frankincense and cinnamon, as well as a similar image of a lictor. ${ }^{63}$ This went well beyond what was practically necessary. Later Pliny censured the excess of Nero when, at the funeral of Poppaea, he purportedly burned more scent than Arabia produced in a year, something Pliny clearly felt was beyond what was socially necessary. ${ }^{64}$ Those among the elite often used

\footnotetext{
${ }^{60}$ Singer (n.52), 21; Groom (n.52), 8; J. Bodel 'Death on Display Looking at Roman Funerals', in B. Bergmann and C. Kondonleon (eds.), The Art of Ancient Spectacle (London, 1999), 267 - see also 265 for examples of burning incense on funerary reliefs.

${ }^{61}$ Pliny $H N$ 12.41.83.

${ }^{62}$ App. Mith. 17.117; Bodel (n.60), 261.

${ }^{63}$ Plut. Vit. Sull. 38.3.

${ }^{64}$ Pliny HN 12.41.83-84.
} 
eastern goods as part of lavish funeral procession, which Statius notes were designed to get the attention. ${ }^{65}$

There were clearly benefits for a family in holding an extravagant funeral. Horace comments that the entire neighbourhood praises a funeral done in style. ${ }^{66}$ The freedman $\mathrm{C}$. Caecilius certainly felt that it was worthwhile to leave instructions that a million sesterces be spent on his funeral $(8 \mathrm{BC})$ and it might be that he (posthumously) used such extravagance to gain the prestige that may have eluded him in life ${ }^{67}$ In some cases the notion of a luxurious funeral could be taken to bizarre extremes as in the case of Pacuvius, governor of Syria, who held mock funerals each day to both honour himself and for his own personal pleasure. ${ }^{68}$ Propertius also mentions the funeral of a courtesan who was cremated still wearing her garnet and beryl rings. ${ }^{69}$ However, there could equally be negative consequences of appearing too miserly. Excessive frugality could do harm as much as a reputation for extravagance. ${ }^{70}$ Persius derides a miserly heir for failing to provide a lavish funerary banquet, a perfumed urn, and not checking if the cinnamon was still fresh or the cassia free from adulteration. ${ }^{71}$

It is clear that funerary rites were both morally necessary as well as socially and politically important. Thus while incense was a practical component of funerary rituals, the need to make an important social statement by providing a suitably lavish or extravagant display meant that many eastern goods were incorporated precisely for their luxurious and

\footnotetext{
${ }^{65}$ Stat. Silv. 2.1.157-62, 5.1.208-22.

${ }^{66}$ Hor. Sat. 2.5.105-106.

${ }^{67}$ Pliny $H N$ 33.47.135; Compare to the funeral of Vespasian which is said to have cost 10 million sesterces Suet. Vesp. 19.2.

${ }^{68}$ Sen. Ep. 12.8-9; Bodel (n.60), 262.

${ }^{69}$ Prop. 4.7.18-19.

${ }^{70}$ Hor. Sat. 1.2.4-11; Sen. Ep. 120.8; Edwards (n.29), 202; see also Suet. Tib. 37.3; Bodel (n.60), 261.

${ }^{71}$ Pers. 6.33-37.
} 
exotic associations. As in the case of Sulla and Nero, incense could be used to extravagant excess, and not merely used as a necessity. In many of the contexts that have been discussed it seems that eastern were in fact the luxuries of necessity.

\section{The Necessity of Luxury}

In many instances eastern goods were sought for their exotic associations and as a form of extravagance that was felt to be useful for social or public spectacles. Yet it is also clear from literary sources that luxury and extravagance themselves were seen by some elites as a necessary part of their social and political image. This is because luxury was felt to play an important role in creating distinctions between those of different social status, and it is admitted as such by some ancient authors. ${ }^{72}$ There were certainly many, Stoics in particular, who condemned luxury for its perceived immoral and effeminate associations, even if some, such as Seneca and Sallust, were themselves condemned for the hypocrisy. ${ }^{73}$ Indeed Horace mocked the Stoics who complained about women proudly walking about weighed down with pearls, while they sat on their cushions of Seric (Chinese) silk writing moralising volumes. ${ }^{74}$

\footnotetext{
${ }^{72}$ A. Wallace-Hadrill Houses and Society in Pompeii and Herculaneum (Princeton, 1994), 4 - he points out the particular example of Cic. Off. 1.138-39; see also Sen. Ep. 69.4 - who mentions that luxury appears to offer pleasure and influence; also Juv. 11 lines 21-22, who mentions how, for Ventidius, expense enhances reputation, though for Rutilus it is called extravagance.

${ }^{73}$ R. Stoneman 'You Are What You Eat. Diet and Philosophical Dianta in Athenaeus' Deipnosophistae', in D. Braund and J. Wilkins (eds.), Athenaeus and His World. Reading Greek Culture in the Roman Empire (Exeter, 2000), 418; P. Wyetzner Sulla's Law on Prices and the Roman Definition of Luxury', in J.-J. Aubert and B. Sirks (eds.), SPECVLVM IVRIS: Roman Law as a Reflection of Social and Economic Life in Antiquity (Ann Arbor, 2002), 19; J. Sekora (n.15), 52-55; Keay (n.6), 72-73.

${ }^{74}$ Hor. Epod. 8 lines 13-20.
} 
Nevertheless many, such as Pliny, complained that luxury was unnatural and a threat to the traditional hierarchy of the Roman elite. ${ }^{75}$ Seneca mocked self-display and the desire to gain a reputation through wealth, for it did not bringing one closer to God, but even in its condemnation, there was acknowledgement that extravagant display did attract attention and indeed awe among some. ${ }^{76}$ Ironically the same language used to condemn luxuries was often employed by those who wished to praise it and for some there was a pleasure to be derived from subverting these moral "rules" ${ }^{77}$ It is in such contexts that eastern goods were felt to be useful.

There was social pressure for an individual to live according to his wealth and not to appear to be miserly. Nero is purported to have claimed that anyone who accounted for every penny was a stingy miser, while the true gentlemen always threw his money about. ${ }^{78} \mathrm{He}$ was, of course, seen as an archetypal bad emperor; nonetheless this does not mean that this sentiment was not shared. In several of Martial's epigrams he heaped contempt on those whom he felt failed to live up to their wealth and status. One such epigram mentions Calenus who, when he was worth two million [sesterces], used to spend lavishly on banquets, but when he became worth ten million was more miserly in his spending. Martial wished he would become worth a hundred million so he would starve to death. ${ }^{79}$ There could also be political pressure to spend lavishly. Some of the rich friends and confidants of Nero were literally forced to express extravagance, including one who was compelled to host a cena

\footnotetext{
${ }^{75}$ Wallace-Hadrill (n.53), 80-96.

${ }^{76}$ Sen. Ep. 31.10 (mocking self-display), 110.17 (attracting attention).

${ }^{77}$ Edwards (n.29), 142; Sen. Ep. 122.14, 18; see also Wallace-Hadrill (n.15), 376.

${ }^{78}$ Suet. Ner. 30.1 .

${ }^{79}$ Mart. Epig. 1.99 (Calenus), see also 1.103 (Scaevola, a shabbily dressed Knight), 2.44 (Sextus - appearing miserly in offering loans/gifts) and 4.51 (Caecilianus - appearing miserly as a result of ceasing to use a litter despite becoming wealthier).
} 
mitellita costing 4,000,000 sesterces, at which the guests were provided with silk turbans instead of the traditional flowers in the hair. ${ }^{80}$

On the other hand, it was not solely through a sense of compulsion that many spent money on luxuries. Some actively sought to use them to their advantage, such as Geminius who allegedly gained Sejanus' friendship through his extravagance (and effeminacy). ${ }^{81}$ Many felt it was their right to spend their wealth in a luxurious manner, as expressed by the faction of the senate that objected to Tiberius' planed introduction of sumptuary laws. These senators' arguments, which Tiberius chose to accept, were that such laws would criminalize the elite and end all distinction. ${ }^{82}$ Women, too, enjoyed the distinction which extravagant displays could bring. Pliny noted how women of equestrian rank would wear pearls suspended from their necks, in this way distinguishing themselves from the lower orders. ${ }^{83}$ It was also felt that such fashionable displays of jewels and pearls could enhance social influence, visibility and wealth, and hopefully attract a suitor. ${ }^{84}$ Indeed, such was the importance and symbolism of these goods that Olson connects a late Roman law code

\footnotetext{
${ }^{80}$ Suet. Ner. 27.3; J. H. D' Arms 'Performing Culture: Roman Spectacle and the Banquets of the Powerful', in B. Bergmann, and C. Kondonleon (eds.), The Art of Ancient Spectacle (London, 1999) 306; see also Suet. Vit. 13.1-2 - who notes that Vitellius used to have himself invited to the dinners of many men on the same day, and that the cost each time never went below 400,000 sesterces.
}

${ }^{81}$ Tac. Ann. 6.14.47; see also Juv. 7 lines 141-45, who notes a lawyer hiring a sardonyx ring in order to impress his clients and receive higher fees.

82 Tac. Ann. 3.54; see Edwards (n.29), 202.

${ }^{83}$ Pliny $H N 33.12 .3$ - who notes that they were worn instead of the stola as a status marker. However, Olson (n.37) 36, notes that the Stola, while considered a status indicator, does not seem to have been popular or widespread.

${ }^{84}$ Claud Honor. 6.523-30 - Olson (n.37), 5, 20; see also Mart. Epig. 8.81 who describes how Gellia loves her pearls, more than her children; also Livy 34.7.8-9, states that as women were denied access to offices that provided status, fashion, adornment and makeup were a means of acquiring status for themselves. 
banning of actresses from wearing real gems and silks to a desire that such items were not devalued in prestige for the elite. ${ }^{85}$

The literary sources make it clear that Roman notions about luxury were not merely connected with pleasure, but also as a means of gaining attention and hopefully prestige. It is noted above that Plutarch felt it was unusual to dine extravagantly in private. He further expresses this sentiment in the statement that 'wealth loses all its radiance without an audience,' when there is 'no one to see or to look on. ${ }^{86}$ Seneca also noted that luxury was not so much possessed as displayed. ${ }^{87}$ It was this desire for public presentation that transcends the notion of simple pleasure. Connected to this was the sense that that the prodigal individual used extravagance as a means to gain notoriety. ${ }^{88}$ Juvenal says as much when he notes that the things which bring most pleasure to the prodigal are those which are priced the highest. ${ }^{89}$ An extreme expression of this sentiment comes in the wearing of emeralds and pearls worth 40,000,000 sesterces by Lollia Paulina at her betrothal party to the Emperor Caligula. Her main concern was to show people proof of their cost and her ownership of such fabulous wealth, even to the extent where she would display receipts to anyone who asked. ${ }^{90}$ Many prestige items were highly priced simply because Romans used price to express the social worth of commodities. High prices were useful in the competition of extravagance. ${ }^{91}$

It is important to remember, however, that it was not the goods themselves which were inherently luxurious, but it is how they were understood in a particular context. This is

\footnotetext{
${ }^{85}$ Olson (n.37), 47; Cod. Th. 15.7.11.

${ }^{86}$ Plut. Mor. 528a - translation from D’ Arms (n.80), 313; see also Plut. Vit. Cat. Mai. 18.3.

${ }^{87}$ Sen. Ep. 110.17.

${ }^{88}$ Edwards (n.29), 190; Sen. Ep. 122.14; Mart. Epig. 12.41.

${ }^{89}$ Juv. 11.16; Edwards (n.29), 189.

90 Pliny $H N 9.117$.

${ }^{91}$ Wyetzner (n.73), 24-25.
} 
apparent from the well-known (if fictional) example of Trimalchio. How the (fictional) guests of the banquet were intended to perceive his displays of wealth, and how it was perceived by readers of the Satyricon was, no doubt, different. ${ }^{92}$ This was clearly also the case with the real life Rufus, who sat in the senators' seating dressed up in finery and sardonyx, despite formerly being a slave. Martial mocks him for using makeup to hide the mark which indicated his servile origin. ${ }^{93}$ Many tried to appear as connoisseurs, as Petronius himself was said to have been. ${ }^{94}$ One method in which this was done was to display wealth in a manner that appeared to show a disregard for it, something which Martial condemns Quintus for failing to do. ${ }^{95}$ It is in these contexts that some highly valuable objects were made to appear as if they were ordinary, as seen with tortoiseshell which was cut up and painted to imitate wood. ${ }^{96}$

It seems, however, that the attempt at emulating the elite by those of lower social status (and possibly, though not necessarily, of lesser wealth) acted as a spur for the elite to maintain a sense of distinction, ensuring their "rightful" place at the top of the social order. Wallace-Hadrill has noticed this phenomenon in the imitation of higher value goods, in less expensive materials, that were diffused among the households in Pompeii. The result was a drive for further innovation (and hence expenditure) for the rich to maintain a distance from those of lower social status, though the use of wealth also made the elite susceptible to

\footnotetext{
${ }^{92}$ See Petron. 30-42; see also Sen. Ep. 27.5, who looks down upon Calvisius Sabinus, a wealthy freedman, who he regarded as uncultured.

${ }^{93}$ Mart. Epig. 2.29; See also Plut. Mor. 523 e.

${ }^{94}$ Tac. Ann. 16.18-19; A. Dalby Empire of Pleasure Luxury and Indulgence in the Roman World (London, 2000b), 10-11, 268; see also Wallace-Hadrill (n.15), 318, 440.

${ }^{95}$ Mart. Epig. 3.62.

${ }^{96}$ Pliny $H N 16.232$.
} 
penetration. ${ }^{97}$ Such emulation was also found in fashion whereby some less wealthy and lower status women would wear imitation gemstones made of glass. ${ }^{98}$ The logical consequence of such emulation and innovation can be seen in Seneca's claim that previously many extravagant dishes were brought to the banquet table for display and notoriety, but that by his day it had become a matter of duty. ${ }^{99}$ A similar sentiment was expressed by Athenaeus who records that by his time (fourth century AD) such habits had spread, with even those of moderate prosperity spending more on banquets than used to be spent at festival and sacrificial rites. ${ }^{100}$ The sentiment expressed by Athenaeus', although clearly moralising in nature, implies the continuing pressure to use such goods in social display even in the context of the greater concentration of wealth at the highest echelons of society that was taking place in the late Roman period. ${ }^{101}$

To summarise, luxurious display was an important element in creating and maintaining status and a public image for many of the elite. It was at events open to the scrutiny of others, such as banquets, religious dedications, and funerary rites, that such luxurious displays were made, often, though not exclusively, through the use of eastern goods. This was, in part, because of their novelty, origin, and in many cases, expense. It is in such contexts that for many members of the elite luxury had become a necessity.

\footnotetext{
${ }^{97}$ Wallace-Hadrill (n.72), 90, 146; Wallace-Hadrill (n.15), 353-54, 440, 449-54; for the desire for emulation as a general facet of human societies see G. Clark Symbols of Excellence: Precious Materials as Expression of Status (Cambridge, 1986).

${ }^{98}$ Olson (n.37), 46; see Pliny HN 37.75-76.197-200, for imitation gemstones.

${ }^{99}$ Sen. Ep. 95.27-28; see also Ep. 114.9, for the spread of luxury from appearance, to furniture, to the dinner table; see also Val. Max. 9.1.3, on how expensive novelties were being added every day to feminine display. ${ }^{100}$ Ath. 6.275 b.

${ }^{101}$ Jongman (n.8) 615-17.
} 


\section{Conclusion}

It has been argued here that the use of static labels and exclusive definitions fails to capture the nuances of perspective and the multitude of uses to which these goods were put. Pepper may have been used in many dishes at banquets, but often in the context of these dishes being presented for their luxurious ostentation. Aromatics may have had an important part to play in religious rituals, but even here deliberate excess and the desire to distinguish oneself by making novel offerings could be part of an act of deliberate public ostentation. Furthermore these same aromatics were used in perfumes, makeup, and even drinks. It is precisely because these goods were open to subjective interpretation, held different meanings in different contexts, and even dual functions and meanings in the same context, that they defy the consistent and universal application of the titles "luxury" or "necessity". This much can be seen in the continual one-upmanship of religious dedications given by emperors and members of the imperial family. The products of the East should not be seen as possessing an inherent nature or function that comes with the label of "luxury" or "necessity". Instead, it should be acknowledged that these goods only achieve a social meaning through the individual contexts in which they were used and through the perceptions of those who observed those uses.

MATTHEW ADAM COBB

\section{SWANSEA UNIVERSITY}

